Article

\title{
Antimicrobial Activities of Different Fractions from Mucus of the Garden Snail Cornu aspersum
}

\author{
Aleksandar Dolashki ${ }^{1}$, Lyudmila Velkova ${ }^{1, *}$, Elmira Daskalova ${ }^{2}$, N. Zheleva ${ }^{2}$, Yana Topalova ${ }^{2}$, \\ Ventseslav Atanasov ${ }^{1}$, Wolfgang Voelter ${ }^{3}$ and Pavlina Dolashka ${ }^{1, *(\mathbb{D})}$ \\ 1 Institute of Organic Chemistry with Centre of Phytochemistry, Bulgarian Academy of Sciences, \\ Acad. G. Bonchev str., bl.9, 1113 Sofia, Bulgaria; adolashki@yahoo.com (A.D.); \\ ventseslav.atanasov@gmail.com (V.A.) \\ 2 Sofia University, St. Kliment Ohridski, Faculty of Biology, Department of General and Applied \\ Hydrobiology, 8 Dragan Tzankov Blvd., 1164 Sofia, Bulgaria; dolashka@orgchm.bas.bg (E.D.); \\ zhelevan@phys.uni-sofia.bg (N.Z.); yanatop@abv.bg (Y.T.) \\ 3 Interfacultary Institute of Biochemistry, University of Tübingen, Hoppe-Seyler-Straße 4, \\ D-72076 Tübingen, Germany; wolfgang.voelter@uni-tuebingen.de \\ * Correspondence: lyudmila_velkova@abv.bg (L.V.); pda54@abv.bg (P.D.)
}

Received: 17 July 2020; Accepted: 24 August 2020; Published: 28 August 2020

check for updates

\begin{abstract}
Natural products have long played a major role in medicine and science. The garden snail Cornu aspersum is a rich source of biologically active natural substances that might be an important source for new drugs to treat human disease. Based on our previous studies, nine fractions containing compounds with $\mathrm{Mw}<3 \mathrm{kDa} ;<10 \mathrm{kDa} ;<20 \mathrm{kDa} ;>20 \mathrm{kDa} ;>30 \mathrm{kDa}>50 \mathrm{kDa}$ and between 3 and $5 \mathrm{kDa} ; 5$ and $10 \mathrm{kDa}$; and 10 and $30 \mathrm{kDa}$ were purified from the mucus of C. aspersum and analyzed by tandem mass spectrometry (MALDI-TOF/TOF). Seventeen novel peptides with potential antibacterial activity were identified by de novo MS/MS sequencing using tandem mass spectrometry. The different fractions were tested for antibacterial activity against $\mathrm{Gram}^{-}$(Pseudomonas aureofaciens and Escherichia coli) and Gram+ (Brevibacillus laterosporus) bacterial strains as well the anaerobic bacterium Clostridium perfringens. These results revealed that the peptide fractions exhibit a predominant antibacterial activity against $B$. laterosporus; the fraction with $\mathrm{Mw} 10-30 \mathrm{kDa}$ against E. coli; another peptide fraction $<20 \mathrm{kDa}$ against $P$. aureofaciens; and the protein fraction $>20 \mathrm{kDa}$ against the bacterial strain C. perfringens. The discovery of new antimicrobial peptides (AMPs) from natural sources is of great importance for public health due to the AMPs' effective antimicrobial activities and low resistance rates.
\end{abstract}

Keywords: Cornu aspersum mucus; antimicrobial peptides; antibacterial activity

\section{Introduction}

Antimicrobial resistance is a major public health problem, which requires scientists and clinicians to identify new efficient antimicrobial agents [1-3]. The World Health Organization (2017) composed a list of antibiotic-resistant bacteria for which the development of novel antimicrobial therapies is highly requested, with the global priority on Acinetobacter baumannii, Pseudomonas aeruginosa, and various species of the Enterobacteriaceae family [4].

Antimicrobial peptides (AMPs) are important components of the innate immune system, providing immediate response to a large set of various pathogens such as bacteria, yeasts, fungi, viruses, and even cancer cells [5-9]. These evolutionarily conserved peptides have been found in virtually all organisms ranging from prokaryotes to humans and display a remarkable structural and functional diversity [6]. Conventional AMPs with molecular masses of 1.5-8 kDa are positively charged, with 15 to 60 amino 
acid residues and $>30 \%$ hydrophobic residues $[10,11]$. AMPs are commonly classified based on their secondary structure into $\alpha$-helical, $\beta$-sheet, or extended/ random-coil structure, and most AMPs belong to the first two groups $[3,11]$.

Since invertebrates lack the adaptive immune system found in vertebrate species, they are reliant solely upon their innate immune systems to counteract invading pathogens. Considering the extraordinary evolutionary success of this group of organisms, it is evident that invertebrate innate immune mechanisms are extremely effective [11]. This has prompted intense studies of invertebrate species in the last few years. Most of the AMPs found in the hemolymph of invertebrates show activity against a mix of microorganisms including bacteria, viruses, and protozoa [12-15].

Novel proline-rich antimicrobial peptides with molecular masses between 3000 and 9500 Da from the hemolymph of Rapana venosa snails were identified [16]. Some of them showed strong antimicrobial activities against Staphylococcus aureus $\left(\mathrm{Gram}^{+}\right)$and low activity against Klebsiella pneumoniae $\left(\mathrm{Gram}^{-}\right)$. Several cysteine-rich peptides belonging to the defensin family also were purified from Mediterranean mussels such as myticin from Mytilus galloprovincialis [17-19]. They are expressed at high levels in hemocytes and are characterized by multiple disulfide bridges, which ensure a precisely folded stable structure for the compact cationic and amphipatic mature peptides. Furthermore, it has been reported that several peptides from the hemolymph of the garden snails $H$. lucorum and H. aspersa exhibit a broad spectrum of antimicrobial activity against S. aureus, S. epidermidis, E. coli, Helicobacter pylori, and Propionibacterium acnes [20,21].

Moreover, the mucus of land snails is a rich source of peptides and proteins with broad-spectrum antibacterial activity. Results indicated that the mucus fraction with Mw between 30 and 100 kDa from the common brown snail $H$. aspersa has a strong antibacterial effect against several strains of P. aeruginosa [14]. The identified proteins in Cornu aspersum with masses $37.4 \mathrm{kDa}, 18.6 \mathrm{kDa}$, and $17.5 \mathrm{kDa}$ appear also to have activity against P. aeruginosa [22]. Additionally, two proteins isolated from the mucus of the African giant land snail Achatina fulica were reported to display a broad spectrum of antibacterial activity against $S$. aureus and different strains of $P$. aeruginosa [23]. Furthermore, a novel cysteine-rich antimicrobial peptide mytimacin-AF with potent antimicrobial activity against $\mathrm{Gram}^{-}$and Gram+ bacteria and the fungal strain C. albicans was isolated and purified from the mucus of the snail A. fulica [23]. Recently, several peptide fractions with antibacterial activities [24,25] and antioxidant properties [26] were isolated from the mucus of the snail C. aspersum. Using mass spectrometry, the primary structures of a series of new antimicrobial peptides were determined.

In the present study, the structure of novel peptides and protein fractions isolated from the mucus of the garden snail $C$. aspersum with antibacterial activity are reported. The antibacterial activity of these fractions was tested against four bacterial strains, including Gram ${ }^{+}$and $\mathrm{Gram}^{-}$bacteria. $^{-}$ Bacterial strains P. aureofaciens AP9 and E. coli NBIMCC $8785\left(\mathrm{Gram}^{-}\right)$, B. laterosporus BT-271 (Gram $\left.{ }^{+}\right)$, and positive anaerobic spore-forming rod-shaped bacterium $C$. perfringens were chosen because of their antibiotic resistance.

\section{Materials and Methods}

\subsection{Mucus Collection and Separation of Different Fractions}

The mucus was collected and purified from C. aspersum snails grown in Bulgarian farms using patented technology without any snail suffering [24]. After ultrafiltration using different membrane filters (10 and $20 \mathrm{kDa}$ ), the crude mucus extract was separated into two fractions: a peptide fraction with Mw below $10 \mathrm{kDa}$ and a fraction containing compounds with Mw above $20 \mathrm{kDa}$. The peptide fraction with Mw below $10 \mathrm{kDa}$ was additionally separated using Amicon ${ }^{\circledR}$ Ultra-15 centrifugal tube filters with 3 and 5 kDa membranes into three fractions. Finally, the following samples were obtained:

Sample 1 -fraction with compounds of $\mathrm{Mw}<3 \mathrm{kDa}$

Sample 2-fraction with compounds of Mw 3-5 kDa

Sample 3-fraction with compounds of Mw 5-10 kDa 
Sample 4-fraction with compounds of $\mathrm{Mw}<10 \mathrm{kDa}$

Sample 5-fraction with compounds of Mw 10-30 kDa

Sample 6-fraction with compounds of $\mathrm{Mw}<20 \mathrm{kDa}$

Sample 7-fraction with compounds of $\mathrm{Mw}>20 \mathrm{kDa}$

Sample 8-fraction with compounds of $\mathrm{Mw}>30 \mathrm{kDa}$

Sample 9-fraction with compounds of $\mathrm{Mw}>50 \mathrm{kDa}$

The following membranes were used for ultrafiltration: discs from ultracel regenerated cellulose from 10 kDa NMW, 50 kDa NMW, 100 kDa NMW (EMD Millipore Corporation, Billerica, MA, USA); $1 \mathrm{kDa}$ polyethersulfone membrane filter (Sartorius Stedim Biotech, Göttingen, Germany); and $20 \mathrm{kDa}$ polyethersulfone (Microdyn Nadir ${ }^{\mathrm{TM}}$ from STERLITECH Corporation, Goleta, CA, USA).

The protein concentration in the samples was determined by the Bradford assay [27].

\subsection{Molecular Mass Analysis and de novo Sequencing of Peptides by Mass Spectrometry}

The isolated peptide fraction with $\mathrm{Mw}<3 \mathrm{kDa}$ (Sample 1) was lyophilized and analyzed by MALDI-TOF-TOF mass spectrometry on an AutoflexTM III. High Performance MALDI-TOF\& TOF/TOF System (Bruker Daltonics, Bremen, Germany), which uses a $200 \mathrm{~Hz}$ frequency-tripled Nd-YAG laser operating at a wavelength of $355 \mathrm{~nm}$. Analysis was carried out after mixing $2.0 \mu \mathrm{L}$ of the sample with $2.0 \mu \mathrm{L}$ of matrix solution $(7 \mathrm{mg} / \mathrm{mL}$ of $\alpha$-cyano-4-hydroxycinnamic acid (CHCA) in $50 \%$ ACN containing $0.1 \%$ TFA), but only $1.0 \mu \mathrm{L}$ of the mixture was spotted on a stainless steel 192-well target plate. The samples were allowed to dry at room temperature before being analyzed. A total of 3500 shots were acquired in the MS mode, and collision energy of 4200 was applied. The mixture of angiotensin I, Glu-1-fibrinopeptide B, ACTH (1-17), and ACTH was used for calibration of the mass spectrometer. The MS/MS spectra were carried out in reflector mode with external calibration using fragments of Glu-fibrino-peptide B. Amino acid sequences of peptides were identified by precursor ion fragmentation using MALDI-MS/MS analysis.

\subsection{Carbohydrate Test}

Nine isolated fractions from the mucus were analyzed by the orcinol-sulphuric test to determine the carbohydrate content. About $2 \mu \mathrm{L}$ of the purified samples were applied to a thin layer plate and air dried. The plate was sprayed with orcinol $/ \mathrm{H}_{2} \mathrm{SO}_{4}$ and heated for $20 \mathrm{~min}$ at $100{ }^{\circ} \mathrm{C}$. The orcinol $/ \mathrm{H}_{2} \mathrm{SO}_{4}$ solution contained $0.02 \mathrm{~g}$ of orcinol, $20 \% \mathrm{H}_{2} \mathrm{SO}_{4}$, and $\mathrm{H}_{2} \mathrm{O}$ to a total volume of $10 \mathrm{~mL}$.

\subsection{SDS-PAGE Electrophoresis}

Protein fractions with antibacterial activity were analyzed by SDS-PAGE electrophoresis. DL-dithiothreitol, acrylamide/bis-acrylamide ( $30 \%$ solution), bromophenol blue sodium salt (Sigma-Aldrich, Schnelldorf, Germany), N, N, N', N'-tetramethylethylenediamine (TEMED), ammonium persulphate (APS) (GE Healthcare, Stockholm, Sweden), and Laemmli sample buffer $(2 \times)$, for SDS PAGE (SERVA, Heidelberg, Germany), were used for electrophoreses analysis. Because commercial Laemmli buffer does not contain any reduction reagent, $10 \mathrm{mM}$ DTT were added as a reducing sample buffer (concentrations refer to $1 \times$ sample buffer). Equal volumes containing approximately $25 \mu \mathrm{g} / \mathrm{lane}$ of the samples dissolved in Laemmli sample buffer and protein standard mixture (Precision Plus Protein ${ }^{\mathrm{TM}}$, All Blue, Bio-Rad, Feldkirchen, Germany) were separated by $12.5 \%$ SDS-PAGE and visualized by staining with Coomassie Brilliant Blue G-250.

\subsection{Antimicrobial Assays}

\subsubsection{Microbial Strains}

The Gram ${ }^{+}$bacterial strains of C. perfringens NBIMCC 8615, B. laterosporus strain BT-271, and Gram ${ }^{-}$ bacterial strains of P. aureofaciens AP9 and E. coli NBIMCC 8785 were used in the assays of the antibacterial 
properties of the peptide fractions. These bacterial strains were chosen as models for pathogenic bacteria from different essential $\mathrm{Gram}^{-}$and $\mathrm{Gram}^{+}$groups. Both strains P. aureofaciens AP9 and B. laterosporus BT-271 were isolated by Topalova (1989) [28] and were characterized as resistant towards aryl-containing xenobiotics and aryl-containing antibiotics possessing the ability to degrade these compounds. E. coli NBIMCC 8785 is representative for bacteria from the Enterobacteriaceae family and was obtained from the National Bank of Industrial Microorganisms and Cell Cultures (NBIMCC) of Bulgaria. The strain C. perfringens [29] was also obtained from the National Bank of Industrial Microorganisms and Cell Cultures.

\subsubsection{Nutrient Media and Culture Conditions}

Solid MPA (Meat-Peptone Agar) medium/nutrient agar was used to investigate the antibacterial activity through cultivation assays. A nutrient broth was used to multiply the microorganisms. A nutrient liquid media was used to multiply the microorganisms. After rehydration in saline, the strains were maintained on slop agar in standard tubes.

\subsubsection{Studies of Antibacterial Activities}

The agar diffusion testing developed in [30] is the official method used in many clinical microbiology laboratories for routine antimicrobial susceptibility testing [31-34].

In the well-known agar disk-diffusion procedure, agar plates are inoculated with a standardized inoculum of the test microorganism. Then, filter paper discs (about $8 \mathrm{~mm}$ in diameter), containing the test compound at a desired concentration, are placed on the agar surface.

Another method is agar well diffusion assay. After culturing, the diameter of the inhibition areas is measured after interaction of the antibacterial agents and test cultures. The concentration of the tested samples is determined by the biuret method [35] using bovine serum albumin as standard. The method is based on measuring the amount of peptide bonds. All antibacterial activities were calculated and compared using the quantitative dimension $\mathrm{mm}^{2} / \mu \mathrm{L}$ sample/mg protein. This allowed for the results to be compared accurately.

Cultivation methods were applied in mesopeptone (nutrient) agar with inoculations run in different conditions:

- Inoculation was carried out by mixing the standardized microbial suspension with liquid agar at a temperature below $40{ }^{\circ} \mathrm{C}$. With this approach, microorganisms penetrate deep inside the nutrient agar. This procedure is modeling the case in which bacteria develop deeply in the skin. For inoculation, the standardized microbial suspension $\left(50 \mu \mathrm{L}\right.$ with a density of $10^{9}$ cell $\left./ \mathrm{mL}\right)$ was spread over the surface of the nutrient solid agar. The peptide fractions $(50 \mu \mathrm{L})$ were applied in the preliminary prepared wells with a diameter of $8 \mathrm{~mm}$. As the negative control without antibacterial effect, $50 \mu \mathrm{L}$ distilled water was applied in the wells.

- Cultivation was performed at $36^{\circ} \mathrm{C}$ for $48-72 \mathrm{~h}$ for P. aureofaciens AP9 and B. laterosporus BT-271. Cultivation for these strains was in aerobic conditions. C. perfringens NBIMCC 8615 was cultivated in an anaerobic camera /Merck/ in a thermostat at $36{ }^{\circ} \mathrm{C}$ for $72 \mathrm{~h}$. E. coli was cultured in a thermostat at $36^{\circ} \mathrm{C}$ for $48 \mathrm{~h}$.

\subsection{Electron Microscopy Assays}

The impact of active fractions isolated from mucus of the garden snail C. aspersum on the cell structure of bacteria was examined by scanning electron microscopy (SEM). All electron microscopic analysis was accomplished by means of SEM-JSM 5510 and LYRA\TESCAN, located in Sofia University "St. Kliment Ohridski", Faculty of Chemistry and Pharmacy, Bulgaria. The samples were treated by means of increasing concentration of ethyl alcohol and covered with a gold layer before the observation. The images of the Illustration of antibacterial effect of peptide fraction 5 on the cells of E. coli are representative micrographs from at least three independent experiments. 


\section{Results}

\subsection{Purification and Characterization of Different Fractions from Mucus}

The purified crude mucus extract was separated into various fractions by ultrafiltration under pressure with membrane filters of different pore sizes of 1, 10, and $20 \mathrm{kDa}$ and centrifugal tube filters with 3 and $5 \mathrm{kDa}$ membranes. As a result, 7 fractions were obtained (Sample 1: Mw <3 kDa; Sample 2: Mw 3-5 kDa; Sample 3: Mw 5-10 kDa; Sample 4: Mw <10 kDa; Sample 5: Mw 10-30 kDa; Sample 6: $\mathrm{Mw}<20 \mathrm{kDa}$, and Sample 7: Mw $>20 \mathrm{kDa}$ ).

\subsubsection{Molecular Mass Analysis and de novo Sequencing of Peptides by Mass Spectrometry}

MS analysis of Sample 1 showed several peptides with $\mathrm{Mw}<3 \mathrm{kDa}$ (Figure 1A). Matrix-assisted laser desorption/ionization time-of-flight mass spectrometry (MS analysis), sequencing the protonated molecular ions $[\mathrm{M}+\mathrm{H}]^{+}$, was applied to determine the molecular mass and amino acid sequences of the peptides. The amino acid sequences of peptides with low molecular weight were identified by de novo sequencing experiments (MS/MS analysis) of the protonated molecule ions $[\mathrm{M}+\mathrm{H}]^{+}$. Following $b$ - and $y$-ions in MS/MS spectrum of peptides at m/z $1059.71[\mathrm{M}+\mathrm{H}]^{+}$, the amino acid sequence MPDGALLGGGGD was identified (Figure 1B).

Using the same method, the amino acid sequences of 17 novel peptides in Sample 1 with molecular masses between 1000 and 2800 Da were identified (Table 1). The isoelectric points (pI) and grand average of hydropathicity (GRAVY) of the peptides were predicted by the ExPASy MW/pI tool program and ExPASy ProtParam tool (Table 1).

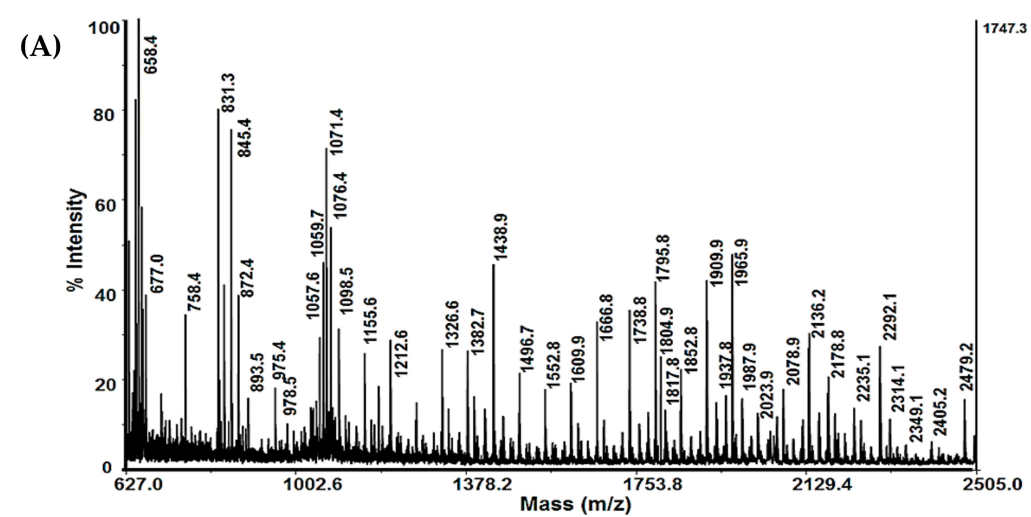

(B)

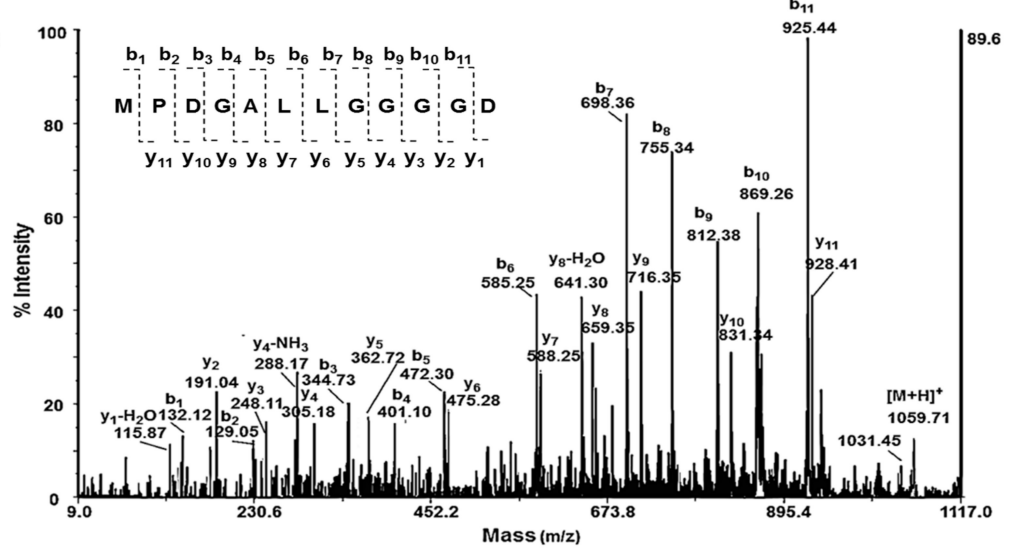

Figure 1. Mass spectrometric analysis of peptide fraction with $\mathrm{Mw}<3 \mathrm{kDa}$ by AutoflexTM III, High Performance MALDI-TOF\&TOF/TOF Systems (Bruker Daltonics, Bremen, Germany): (A) MALDIMS spectrum; (B) MALDI-MS/MS spectrum of peptide $[\mathrm{M}+\mathrm{H}]^{+}$at m/z 1059.71 Da. 
Table 1. Amino acid sequences of peptides from mucus of the garden snail C. aspersum, identified by de novo sequencing on MALDI-MS/MS.

\begin{tabular}{|c|c|c|c|c|c|c|}
\hline No & Amino Acid Sequence of Peptides & $\begin{array}{c}\text { Exper.Mass } \\
{[\mathrm{M}+\mathrm{H}]^{+}} \\
\mathrm{Da}\end{array}$ & $\begin{array}{l}\text { Calcul. } \\
\text { Monois. } \\
\text { Mass, Da }\end{array}$ & pI & $\begin{array}{l}\text { Grand Average of } \\
\text { Hydropathicity } \\
\text { (GRAVY) }\end{array}$ & Net Charge \\
\hline 1 & DLTLNGLSP्K & 1057.58 & 1056.58 & 5.84 & -0.300 (hydrophilic) & $-1 /+1$ \\
\hline 2 & MPDGALLGGGGD & 1059.71 & 1058.47 & 3.56 & +0.058 (hydrophobic) & $-2 / 0$ \\
\hline 3 & DGPADNAQGAVG & 1071.44 & 1070.46 & 3.56 & -0.600 (hydrophilic) & $-2 / 0$ \\
\hline 4 & SLEERDIQS & 1076.44 & 1075.49 & 4.14 & -0.980 (hydrophilic) & $-3 /+1$ \\
\hline 5 & GGLLAAGAGGGGAAV & 1098.53 & 1097.58 & 5.52 & +1.200 (hydrophobic) & $0 / 0$ \\
\hline 6 & LGLGNGGAGGGLVGG & 1155.57 & 1154.60 & 5.52 & +0.687 (hydrophobic) & $0 / 0$ \\
\hline 7 & LNLGLDAGGGDPGG & 1212.57 & 1211.58 & 3.56 & -0.093 (hydrophilic) & $-2 / 0$ \\
\hline 8 & FNHKSLPKLEN & 1326.64 & 1325.64 & 8.60 & -1.227 (hydrophilic) & $-1 /+2$ \\
\hline 9 & NLVGGLSGGGRGGAPGG & 1382.70 & 1381.71 & 9.75 & -0.024 (hydrophilic) & $0 /+1$ \\
\hline 10 & LGGLGGGGAGGGGLVGEP苗 & 1438.86 & 1437.72 & 4.00 & +0.439 (hydrophobic) & $-1 / 0$ \\
\hline 11 & NLVGGSGGGGRGGANPLG & 1496.73 & 1495.75 & 9.75 & -0.217 (hydrophilic) & $0 /+1$ \\
\hline 12 & NGP्PGGGLGGSLVNGDP्XK & 1552.76 & 1551.76 & 5.84 & -0.735 (hydrophilic) & $-1 /+1$ \\
\hline 13 & GLLGGGGGAGGGGLVGGLLNG & 1609.94 & 1608.86 & 5.52 & +0.776 (hydrophobic) & $0 /+1$ \\
\hline 14 & MGGLLGGVNGGGKGGGGP्PGAP & 1666.83 & 1665.83 & 8.50 & +0.005 (hydrophobic) & $0 /+1$ \\
\hline 15 & MLLNAKWAPHSTGPPNA & 1804.91 & 1803.91 & 8.52 & -0.400 (hydrophilic) & $0 /+1$ \\
\hline 16 & LPFLGLVGGLLGGSVGGGGGGGGPAL & 2136.20 & 2135.17 & 5.52 & +1.023 (hydrophobic) & $0 / 0$ \\
\hline 17 & DVESLPVGGLGGGGGGAGGGGLVGGNLGGGAG & 2479.20 & 2478.21 & 3.67 & +0.353 (hydrophobic) & $-2 / 0$ \\
\hline
\end{tabular}

\subsubsection{Glycosylation Screening}

Glycosylation is one of the most prevalent post-translational modifications of proteins, with a defining impact on their structures and functions. The glycosylation of AMPs can influence their antimicrobial activity, and their ability to affect host immunity, target specificity, and biological stability [36-39]. The favorable impact of glycosylation on pharmacokinetic properties of the native peptides leads to an increase in their oral absorption and bioavailability [37]. The importance of glycosylation has been well studied among the insect AMPs, such as diptericin and formaecin. In all the above-mentioned peptides, the absence of glycosylation abolishes their antimicrobial activity [38-40]. Differently glycosylated peptides exhibit differential effects among each other when tested against several Gram-negative bacterial strains. The change of monosaccharide moiety and/or its anomeric configuration in formaecin I and drosocin resulted in a decrease in the antibacterial activity in comparison to that of the native glycopeptide, but the extent of the decrease in antibacterial activity of the glycosylated drosocin analogs was less [40].

Glycosylation of AMP does not necessarily result in generation of an efficacious peptide and can sometimes lead to a loss of activity or functionality [41]. Therefore, it is important to take into consideration the differential expression of peptides among hosts to avoid undesired types of glycosylation [42]. A screening of the fractions from mucus performed by orcinol/ $\mathrm{H}_{2} \mathrm{SO}_{4}$ assay identified several glycosylated fractions. As is shown in Figure 2 all fractions except the control fraction water (position 8) change the color in the orcinol-sulfuric acid test applied to the silica gel plate. The peptide fraction with compounds with Mw 3-10 kDa (Figure 2, position 3), and protein fraction 7 with compounds with Mw above $20 \mathrm{kDa}$ (Figure 2, position 7) show a very intensive brown color, probably as more of the compounds in these fraction are glycosylated. 
1

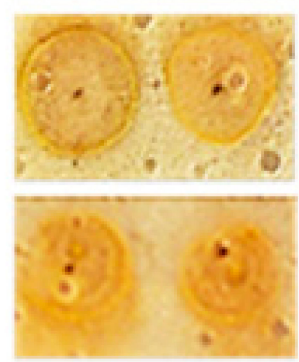

6
2

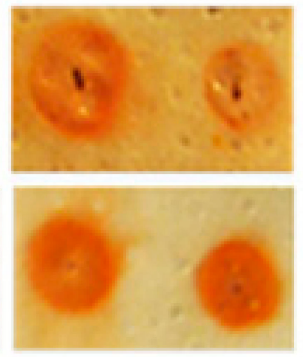

7
3

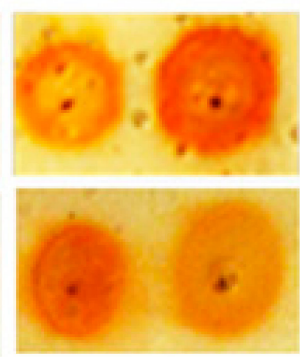

8
4

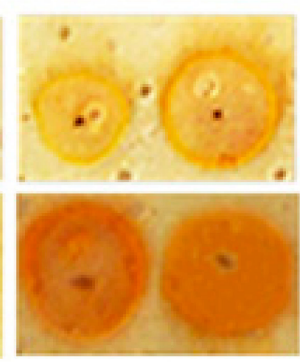

9
5

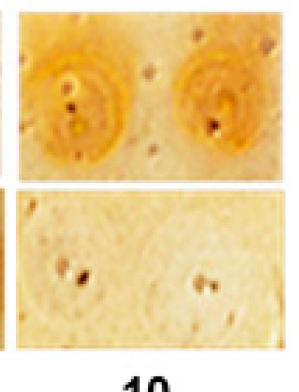

Figure 2. Orcinol-sulphuric acid test applied on to a silica-gel plate of different fractions isolated from mucus of the garden snail C. aspersum. The spots on position (1) fraction with $\mathrm{Mw}<1 \mathrm{kDa}$; position (2) fraction with $\mathrm{Mw}<3 \mathrm{kDa}$; position (3) fraction with Mw 3-10 kDa; position (4) fraction with Mw 5-10 kDa; position (5) fraction with $\mathrm{Mw}<10 \mathrm{kDa}$; position (6) fraction with $\mathrm{Mw}<20 \mathrm{kDa}$; position (7) fraction with Mw above $20 \mathrm{kDa}$; position (8) fraction with compounds of $\mathrm{Mw}>30 \mathrm{kDa}$;

(9) fraction with compounds of $>50 \mathrm{kDa}$; (10) control: contains only water.

\subsection{Antibacterial Activity of Different Fractions from Mucus of the Garden Snail C. aspersum}

It is known that the Gly and Pro content in peptides plays a crucial role in the activity against different bacteria. Understanding the mechanism of these new antibacterial compounds from the mucus of $C$. aspersum may contribute to the potential of anti-infection therapeutics. Therefore, the antibacterial activity of Sample 1 (compounds with $\mathrm{Mw}<3 \mathrm{kDa}$ ), Sample 2 (compounds with $\mathrm{Mw}$ 3-5 kDa), Sample 3 (compounds with Mw 5-10 kDa), Sample 4 (compounds with $\mathrm{Mw}<10 \mathrm{kDa}$ ), Sample 5 (compounds with Mw 10-30 kDa), Sample 6 (compounds with $\mathrm{Mw}<20 \mathrm{kDa}$ ), and Sample 7 (compounds with $\mathrm{Mw}>20 \mathrm{kDa}$ ), isolated from mucus of the garden snail was analyzed against Gram+ bacterial strains of $C$. perfringens and B. laterosporus BT-271 and $\mathrm{Gram}^{-}$bacterial strains of P. aureofaciens AP9 and E. coli NBIMCC 8785.

Two approaches (agar disk-diffusion method and agar well diffusion assay) were used to study antimicrobial effects at depth and on the surface [34]. The surface application gives information about the antibacterial effect when bacteria are located on the surface of the tissue. Applying agar well diffusion assays give information about antibacterial effects of the AMPs when infection is spread deep within the tissues.

The results of tracing the antibacterial activity of nine fractions isolated from mucus against C. perfringens NBIMCC 8615 compared to the antibacterial activity against other test cultures (strains) are shown in Figure 3A,B. No antibacterial activity at surface inoculation of the bacterial material is observed in Figure 3A. Antibacterial activity of all tested peptide and protein fractions is consistent with the anaerobic nature of the bacterium. Even though the cultivation is in aerostatic chambers, under anaerobic conditions, neither of the five fractions isolated from the mucus inhibited bacterial strain growth.

The obtained results reveal that three peptide fractions, those with $\mathrm{Mw}<3 \mathrm{kDa}$ (Sample 1), Mw 3-5 kDa (Sample 2), and Mw 5-10 kDa (Sample 3), have antibacterial activity against the Gram ${ }^{+}$ bacterial strain B. laterosporus BT-271, and the most active one is Sample 3 (Figure 3A), which is one of the two fractions with the highest carbohydrate content (orcinol/ $\mathrm{H}_{2} \mathrm{SO}_{4}$ test, Figure 2). The compounds with Mw 10-30 kDa (Sample 5) possess a very high inhibition effect against E. coli NBIMCC 8785 (Figure 3A). Samples 6, 7, 8, and 9 were also tested in agar disc diffusion tests and they did not show an inhibitory effect. 

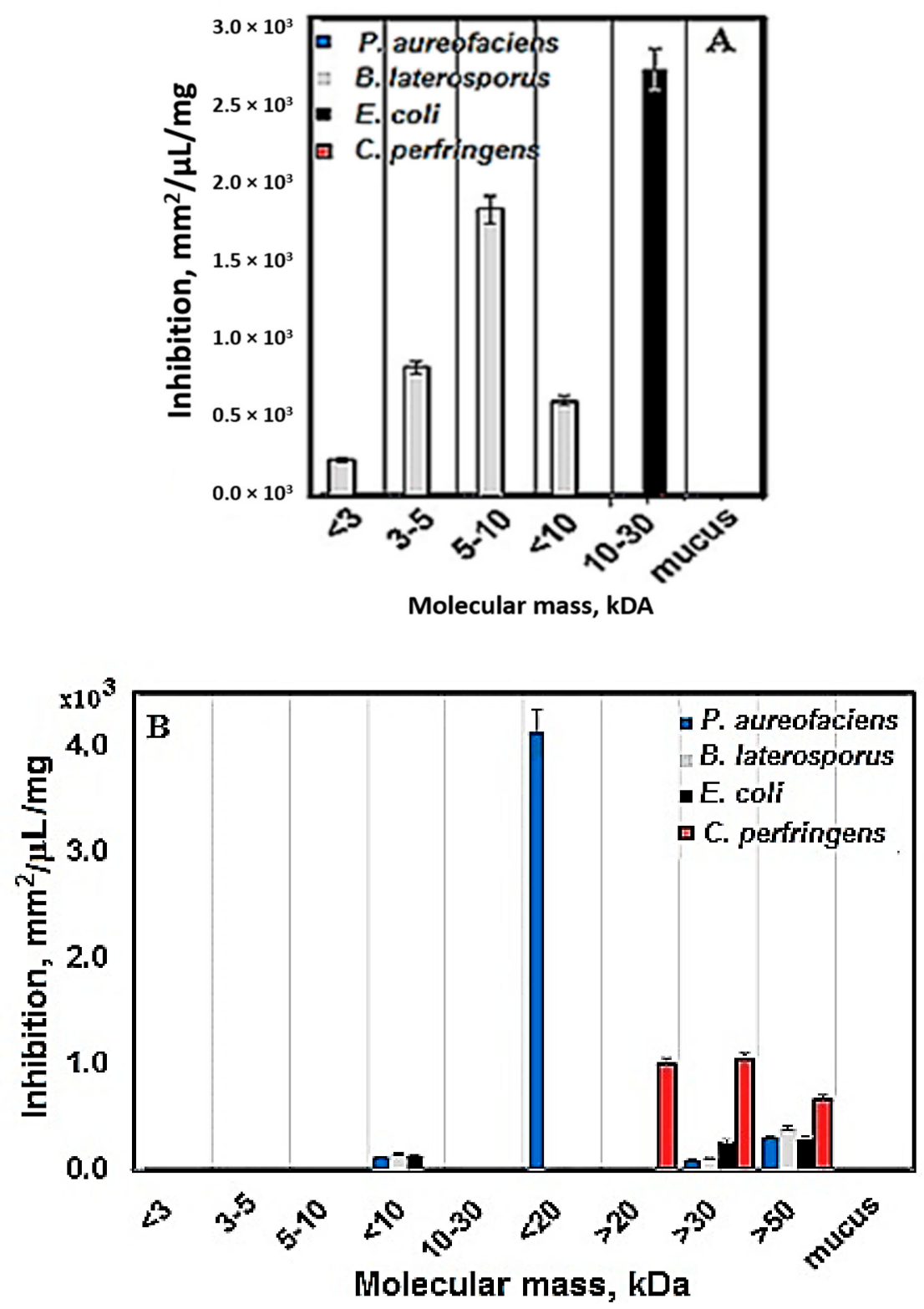

Figure 3. Comparative analysis of the antibacterial activity of Sample 1 (compounds with $\mathrm{Mw}<3 \mathrm{kDa}$ ), Sample 2 (compounds with Mw 3-5 kDa), Sample 3 (compounds with Mw 5-10 kDa), Sample 4 (compounds with Mw <10 kDa), Sample 5 (compounds with Mw 10-30 kDa), Sample 6 (compounds with $\mathrm{Mw}<20 \mathrm{kDa}$ ), Sample 7 (compounds with Mw $>20 \mathrm{kDa}$ ), Sample 8 (compounds with Mw $>30 \mathrm{kDa}$ ), Sample 9 (compounds with $\mathrm{Mw}>50 \mathrm{kDa}$ ), and initial mucus extract (mucus) isolated from the garden snail against Gram ${ }^{+}$bacteria C. perfringens and B. laterosporus and Gram- bacteria P. aureofaciens and E. coli: (A) surface inoculation of bacteria by agar disk-diffusion assay; (B) deep inoculation of bacteria by agar well diffusion assay. Antibacterial activity was measured in inhibition $\left(\mathrm{mm}^{2} / \mu \mathrm{L} / \mathrm{mg} \mathrm{Pr}\right)$.

Comparative analysis of the antibacterial activity of different samples isolated from mucus of the garden snail C. aspersum upon deep inoculation of bacteria reveals that Sample 6 with Mw $<20 \mathrm{kDa}$ has highest antibacterial activity against the $\mathrm{Gram}^{-}$bacterial strain of P. aureofaciens AP9 $\left(3510.00 \mathrm{~mm}^{2} / \mu \mathrm{L} / \mathrm{mg}\right.$ protein) in comparison to that of the other tested fractions, whereas Sample 4 with $\mathrm{Mw}<10 \mathrm{kDa}$ shows insignificant antibacterial activity against B. laterosporus strain BT-271 $\left(\mathrm{Gram}^{+}\right)$ and $\mathrm{Gram}^{-}$bacterial strains of P. aureofaciens AP9 and E. coli NBIMCC 8785 (Figure 3B) (for Sample 4 Supplementary Materials SI2: Figures S1 and S2). Furthermore, only one tested fraction, with high carbohydrate content (Sample 7 with $\mathrm{Mw}>20 \mathrm{kDa}$ ) (Figure 3B) showed high antibacterial activity 
against C. perfringens NBIMCC 8615 . This anticlostidial activity is relatively high $\left(1400.17 \mathrm{~mm} / \mathrm{mg}^{2}\right.$ protein $/ \mu \mathrm{Mol}$ ) in comparison to those of the other tested peptide and protein fractions. These results indicate that upon deep inoculation of the microbial material, the protein fraction is of interest for therapeutic purposes against clostridia-induced infections.

The large sterile zones formed due to a strong inhibition effect of Fraction 7 against $C$. perfringens NBIMCC 8615 is illustrated with three repetitions in Figure 4A; they are due to the deep inoculation of the bacteria in comparison to that of the control. For comparison, the antibacterial effect of antimicrobial compounds (AMCs) (Sample 5) against E. coli NBIMCC 8785 at surface inoculation of the bacteria is illustrated in Figure 4B. It clearly shows that fraction 7 of the AMCs displays an antibacterial effect against C. perfringens NBIMCC 8615.
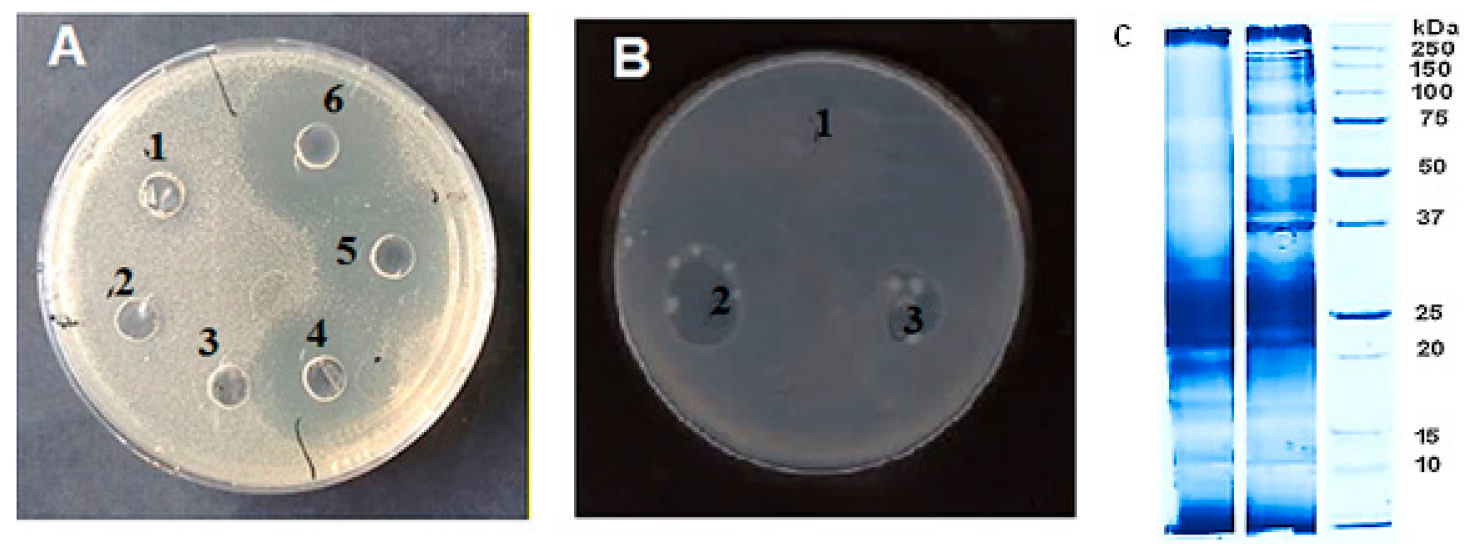

Figure 4. (A) Illustrations of sterile areas in investigation of antibacterial activity against the model bacteria of Sample 7 (compounds with $\mathrm{Mw}>20 \mathrm{kDa}$ ), against C. perfingens at deep anaerobic cultivation; positions 1, 2, and 3: control; positions 4, 5, and 6: Sample 7. (B) Antibacterial activity of Sample 5 (fraction with Mw 10-30 kDa) against E. coli NBIMCC 8785 at surface cultivation: position 1: Control, position 2 and 3: Sample 5. (C) 12.5\% SDS-PAGE with Coomassie Brilliant Blue G-250 staining of protein fractions: position 1 (Samples 5 with Mw 10-30 kDa), position 2 (Samples 7 with Mw $>20 \mathrm{kDa}$ ), and position 3 (standard protein marker, Protein Prestained Standards, Biorad).

This allows us to speculate that the fractions may become a candidate for medical treatment of anaerobic infections caused by clostridia. Two fractions with antibacterial activity were subject to SDS-PAGE in order to determine the approximate size of the antimicrobial substances. The electrophoresis (Figure 4C) revealed several compounds in region 10-30 kDa (bands at $\sim 12 \mathrm{kDa}$, 17-20kDa kDa, $22 \mathrm{kDa}$, and between 25 and $30 \mathrm{kDa}$ ) and proteins in fraction $>20 \mathrm{kDa}$ (bands at $\sim 37 \mathrm{kDa}, 42 \mathrm{kDa}$, between 45 and $50 \mathrm{kDa} ; 65 \mathrm{kDa}, 80$ and $90 \mathrm{kDa} ; 150$ and $250 \mathrm{kDa}$ ).

To shed light on the mechanism of antibacterial action, we studied the effect of the active fraction with Mw 10-30 kDa on the cell structure of the Gram- bacterial strain E. coli NBIMCC 8785 by Scanning Electron Microscopy (SEM).

Figure 5 shows the results obtained by SEM from the control with $18 \mathrm{~h}$ culture of $E$. coli in nutrient broth (Figure 5A) and the damaged bacterial wall and membranes of cell of $18 \mathrm{~h}$ culture of E. coli in nutrient broth after $1 \mathrm{~h}$ action of peptide fraction 5 with magnification 10,000× (Figure 5B) and $30,000 \times$ (Figure 5C). The deformation of the shape of the bacterial cells can be seen clearly. SEM pictures show the formation of blowing at the two ends as well as a craw in the middle of the bacterial cells. 


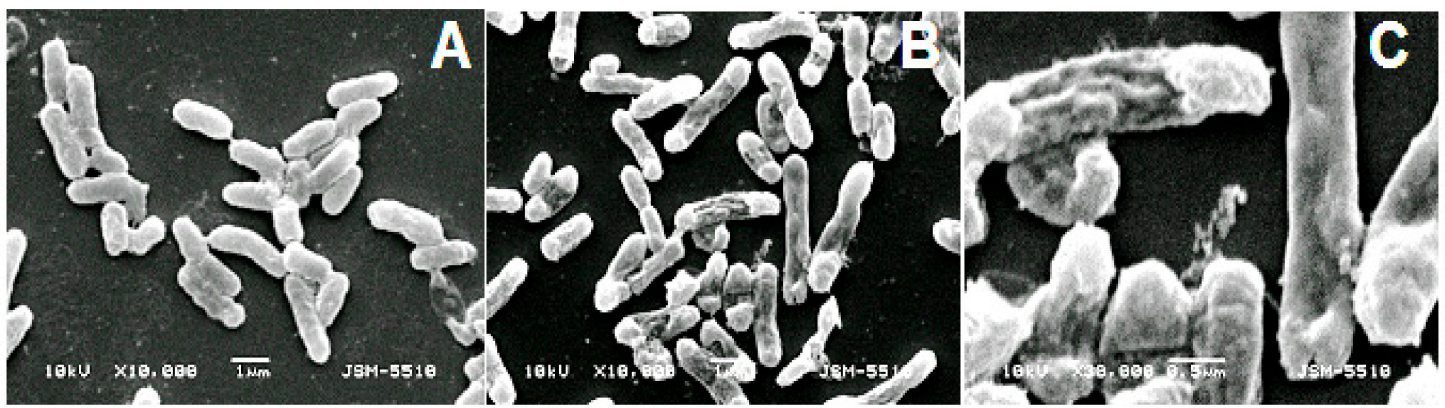

Figure 5. Illustration of antibacterial effect of peptide fraction 5 on the cells of E. coli: (A) Control, $18 \mathrm{~h}$ culture of E. coli in nutrient broth; (B) Damaged membranes and deformation of cell of $18 \mathrm{~h}$ culture of E. coli in nutrient broth after $1 \mathrm{~h}$ action of peptide fraction 5: 10,000x; (C) Damaged membranes and deformation of cell of $18 \mathrm{~h}$ culture of $E$. coli in nutrient broth after $1 \mathrm{~h}$ action of peptide fraction 5, Magnification 30,000×. The images in Figure 5 are representative micrographs from at least three independent experiments.

\section{Discussion}

The discovery of new AMCs from natural sources is of great importance for public health, since these molecules are pharmacological candidates due to their effective antimicrobial activity and low resistance rates. In the case of AMPs, the resistance against them is not prevalent, although AMPs have been exposed to microbes for millions of years [43]. Besides, mutations in the microbes during the course of evolution led to the diversification of AMPs [44].

In our previous work we determined the primary structure and antimicrobial activity of nine peptides produced by the mucus of the garden snail C. aspersum, in particular against $\mathrm{Gram}^{-}$ P. aureofaciens AP9 and $\mathrm{Gram}^{+}$B. laterosporus BT271 bacteria [25]. C. aspersum and H. aspersa are two alternative names for the same species of snail. The taxonomically correct name is $C$. aspersum, but the previous name $H$. aspersa is used more widely. We hypothesized that other peptides from the mucus would also be effective against bacterium C. perfringens NBIMCC 8615.

In certain primary structures (Table 1), many peptides contain amino acid residues such as glycine $(\mathrm{G})$, proline $(\mathrm{P})$, leucine $(\mathrm{L})$, valine $(\mathrm{V})$, tryptophan $(\mathrm{W})$, aspartic acid $(\mathrm{D})$, phenylalanine $(\mathrm{F})$, and arginine (R), which are typical for peptides with antimicrobial activity. Many AMPs are unstructured in free solution and fold into their final conformation upon partitioning with biological membranes. Generally, these proteins can attain diverse conformations such as $\alpha$-helices, $\beta$-sheets, mixed conformations, and extended structures [3,44-46]. Analyses using the ExPASy ProtParam tool indicate that the mucus fractions with $\mathrm{Mw}<3 \mathrm{kDa}$ contain both cationic and anionic AMPs, but are dominated by cationic AMPs. Most of the peptides identified in fractions with $\mathrm{Mw}<3 \mathrm{kDa}$ are characterized by an amphipathic structure and display generally hydrophobic surfaces (Table 1). This fact is considered as a prerequisite for the disruption of biological membranes and direct cell lysis [3,10,45,46]. It is known that cationic AMPs kill microbes via mechanisms that predominantly involve interactions between the peptide's positively charged residues and anionic components of target cell membranes. These interactions can then lead to a range of effects including membrane permeabilization, depolarization, leakage, or lysis resulting in cell death. Peptides bind to the membrane surfaces with their hydrophobic sides anchored in the hydrophobic lipid core of the bilayer. There are multiple mechanism models to explain the action of these peptides, including the toroidal pore model, the barrel-stave model, the carpet model, and so on [3,47-49]. Some of positively charged AMPs may penetrate into the cell to bind intracellular molecules that are crucial to cell living. They can interact with bacterial ribosomal proteins and induce cell death via interacting with intracellular DNAs and RNAs. [48,50,51]. Recent reports have shown that proline-rich AMPs bind to the 70S ribosome as the main target and interfere with the process of protein synthesis [52,53]. 
Some of the identified peptides in Table 1 have a primary structure similar to glycine-rich linear antimicrobial peptides, such as Ctenidin1-3 with activity against the Gram ${ }^{-}$bacterium E. coli, isolated and characterized from hemocytes of the spider Cupiennius salei [54]. In addition, acanthoscurrins isolated from the hemocytes of the spider Acanthoscurria gomesiana act against Gram-negative bacteria, E. coli, and the yeast Candida albicans and are characterized as cationic peptides with high glycine content [55]. Using alignment of amino acid sequences presented in Table 1 with CAMPSing (http://www.campsign.bicnirrh.res.in/blast.php) [56], the peptides number 6 showed $72 \%$ identity with Ctenidin 1 and Ctenidin 3, as well as $~ 79 \%$ identity with two isoforms of AMP acanthoscurrin (see Supplementary Materials SI 1). Peptides numbers 9, 10, 13, and 17 have about 71-76\% identity with two isoforms of acanthoscurrin (see Supplementary Materials SI 1).

Some of the identified peptides shown in Table 1 belong to anionic antimicrobial peptides (AAMPs), which have been increasingly identified in invertebrates, vertebrates, and plants over the last decade. Previous research also identified AAMPs in mucus fractions with Mw below $10 \mathrm{kDa}$ isolated from garden snail H. aspersa [24,25]. Usually, AAMPs show antibacterial activity, but a number of them are multifunctional, variously showing antifungal, anticancer, and neuropeptide activity, and they have the potential to become conventional antibiotics $[3,10,57,58]$. Some of the antimicrobial mechanisms proposed for these peptides include toroidal pore formation and membrane interaction according to the Shai-Huang-Matsazuki carpet model along with $\mathrm{pH}$-dependent amyloidogenesis and membranolysis via tilted peptide formation [3,10,57-59]. AAMPs generally adopt amphiphilic structures. For a number of these peptides, post-translational modifications are essential for antimicrobial activity [53,60-62]. Membrane interaction appears to be a key to the antimicrobial function of AAMPs. The architecture of AAMPs is very diverse from alpha-helical peptides in some amphibians to cyclic cysteine knot structures observed in some plant proteins, because of which, in some cases, the mechanisms underlying the antimicrobial action of these peptides are not fully clarified [58,59,63-65].

The detected peptides (shown in Table 1, numbers 2, 5, 6, 9, 10,11, 13, 14, 16, and 17) containing high levels of glycine and leucine residues belong to a new class of Gly/Leu-rich antimicrobial peptides. High homology (above 70.0\%, identified from alignment with CAMPSing, (see Supplementary Materials SI 1) was found between amino acid sequences of peptide numbers 2, 5, 13, 14, 16, (Table 1) and leptoglycin (GLLGGLLGPLLGGGGGGGGGLL, pI 5.52, GRAVY 1.073) [66], which inhibits the growth of Gram ${ }^{-}$P. aeruginosa, E. coli, and Citrobacter freundii strains, but it did not show antimicrobial activity against Gram ${ }^{+}$bacteria. Our previous studies have also shown the presence of peptides with similar amino acid sequences in the extracts of the garden snail [24,25].

Proline-rich AMPs, with a high content of Pro, Gly, and Arg residues, are an important group of AMPs predominantly active against Gram ${ }^{-}$bacteria [52,67-69]. Previous studies have shown [69], if Pro residues are inserted into the sequences of $\alpha$-helical AMPs, their ability to permeabilize the bacterial cytoplasmic membrane decreases substantially along with the number of Pro residues incorporated, which could explain our results. Proline-rich peptides, previously known to bind to heat shock proteins, have been shown to inhibit protein synthesis [70,71]. Due to our results from the identified sequences, 12 peptides of the identified sequences contain 1 to 3 Pro amino acid residues in the polypeptide chain. In nine peptides, Pro residues are incorporated in the C-terminal region of the polypeptide chain, but only in 5 peptides are Pro residues located in the N-terminal region. Two peptides contain proline residues both in the $\mathrm{N}$-terminal and $\mathrm{C}$-terminal polypeptide chain. Moreover, one proline residue was found in the center of the polypeptide chain for two peptides (numbers 8 and 15). Although Pro-residue is commonly known as an $\alpha$-helix breaker, proline residues have been found in the alpha-helical regions of many peptides and proteins, as well as AMPs, such as gaegurin, leptoglycin, buforin, brevinin, and others [66,72-74].

The alignment in BLAST has shown, that three peptides (numbers 1, 4, and 8) demonstrate high homology with hemocyanins isolated from the snails $H$. aspersa, H. pomatia, and H. lucorum (https://blast.ncbi.nlm.nih.gov) (see Supplementary Materials SI 1). Peptide number 1 shows 100\% identity with a fragment from the hemocyanins' subunits $\beta-\mathrm{HaH}$ (H. aspersa, Sequence ID: AYO86685.1), 
$\beta-\mathrm{HlH}$ (H. lucorum Sequence ID: AEO51766.1), and $\beta-\mathrm{HpH}$ (H. pomatia, Sequence ID: AYO86688.1) and $78 \%$ identity with Keyhole limpet hemocyanin. Peptide 4 is $100 \%$ identical with the sequence from a fragment of subunits from $\beta-\mathrm{HaH}$ (H. aspersa, Sequence ID: AYO86685.1), $\beta-\mathrm{HlH}$ (H. lucorum, Sequence ID: AEO51766.1), $\beta-\mathrm{HpH}$ (H. pomatia, Sequence ID: AYO86688.1), and $\alpha_{\mathrm{D}}-\mathrm{HaH}$ (H. aspersa, Sequence ID: AYO86683.1). Peptide number 8 shows $73 \%$ identity with $\beta-\mathrm{HaH}, \beta-\mathrm{HlH}$, and $\beta-\mathrm{HpH}$. Probably, proteolytic processes may have led to the appearance of these peptides in the mucus. Furthermore, the majority of known AMPs originate from processing of larger inactive proteins, and some studies suggest that biologically active proteins, such as hemocyanins [75] or hemoglobins [76], can be processed to produce bioactive compounds [13]. Some of the identified peptides contain high levels of glycine and leucine residues, as well as up to thee proline residues, which is probably important for the stability of their antimicrobial activity. A comparison of the alignment of amino acid sequence of the peptides from the mucus of the garden snail $H$. aspersa (presented in Table 1 ) with databases by software CAMPSing revealed high identification (above $70 \%$ ) with known AMPs (see Supplementary Materials SI 1). This fact confirms their affiliation with the AMPs family.

In the present study the antibacterial activities of novel peptides and protein fractions isolated from the mucus of the garden snail C. aspersum against aerobic bacterial strains $P$. aureofaciens AP9 and E. coli NBIMCC 8785, B. laterosporus BT-271, and positive anaerobic spore-forming rod-shaped bacterium $C$. perfringens by surface and deep inoculation of the bacteria are presented.

Results from comparative analysis of the antibacterial activity of fractions against $C$. perfringens NBIMCC $8615\left(\mathrm{Gram}^{-}\right)$and aerobic tested bacterial strains P. aureofaciens AP9, E. coli NBIMCC 8785, B. laterosporus BT-271 by surface and deep inoculation of the bacteria reveal that a protein fraction with $\mathrm{Mw}>20 \mathrm{kDa}$ (one of the two fractions with the highest carbohydrate content) is the most effective against the bacterial strain $C$. perfringens at deep anaerobic cultivation.

Differences in the antibacterial activities of the new peptides and protein fractions isolated from the mucus of the garden snail $C$. aspersum were also found between the aerobic bacterial strains $P$. aureofaciens AP9 and E. coli NBIMCC $8785\left(\mathrm{Gram}^{-}\right)$and B. laterosporus BT-271 (Gram $\left.{ }^{+}\right)$upon surface and deep inoculation of the bacteria.

The obtained results reveal that peptide fractions (Samples 1, 2, and 3) exhibit a predominant antibacterial activity against the $\mathrm{Gram}^{+}$bacterial strain B. laterosporus BT-271, whereas peptide fractions with $\mathrm{Mw}<20 \mathrm{kDa}$ have significant antibacterial activity against $\mathrm{Gram}^{-}$bacterial strains $P$. aureofaciens AP9 upon deep inoculation of the bacterium. The presented results show that higher carbohydrate content of the peptide fractions (Samples 1, 2, and 3) leads to higher antibacterial activity against B. laterosporus BT-271.

We hypothesize the presence of a synergistic effect of peptides in a fraction below $3 \mathrm{kDa}$ and a fraction of 3-10 kDa and in polypeptides with a molecular weight between 10 and $20 \mathrm{kDa}$ (at $12 \mathrm{kDa}$, between 17 and $20 \mathrm{kDa}$ ), which is due to the strong antibacterial activity against $P$. aureofaciens AP9 in deep inoculation of the bacterium. The fraction with $\mathrm{Mw}$ 10-30 kDa exhibits the highest antibacterial activity using surface inoculation of bacterial strain E. coli NBIMCC 8785.

From electrophoresis (Figure 4C), it was clear that the compounds active against $P$. aureofaciens AP9 in the C. aspersum mucus were those identified at $\sim 12 \mathrm{kDa}$, between 17 and $20 \mathrm{kDa}, \sim 22 \mathrm{kDa}$, and between 25 and $30 \mathrm{kDa}$. Recently, two peptides (one $17.5 \mathrm{kDa}$ and one $18.6 \mathrm{kDa}$ ) were identified in the mucus of $C$. aspersum that appear to have activity against $P$. aeruginosa [22].

It is likely that the proteins determined at $\sim 37 \mathrm{kDa}, \sim 42 \mathrm{kDa}, 45-50 \mathrm{kDa}, \sim 65 \mathrm{kDa}, 80-90 \mathrm{kDa}$, and between 150 and $250 \mathrm{kDa}$ (electrophoresis, Figure $4 \mathrm{C}$ ) are responsible for the anticlostidial effect. Some of the found proteins may be related to a new protein named aspernin with a molecular weight of $37.4 \mathrm{kDa}$, a protein with a molecular weight $\sim 50 \mathrm{kDa}$, determined previously in fractions from the mucus of C. aspersum with anti-pseudomonal properties [22], as well as a protein with $\mathrm{Mw} 50.81 \mathrm{kDa}$ from A. fulica mucus [77]. Furthermore, the protein determined to be between 80 and $90 \mathrm{kDa}$ probably corresponds of a protein with MW of $83.67 \mathrm{kDa}$ (achacin) isolated from A. fulica mucus, active against 
Streptococcus mutans and Actinobacillus actinomycetemcomitans [77]. Our new data are in agreement with the antimicrobial properties of the mucus from H. aspersa, and A. fulica [15,22,77].

The combination of two vectors of action of protein fractions $>20 \mathrm{kDa}$ against clostridial infections, an antibacterial and a regenerative effect, will be the basis for the development of synergistic therapeutic agents.

Our results show that the antibacterial activity of fractions with Mw 10-30 $\mathrm{kDa}$ (Fraction 5 with Mw 10-30 kDa) induces serious damage of the bacterial membrane, changing of the shape and activity of the bacteria strain E. coli NBIMCC 8785 (Figure 5A-C). These results will be extended by investigations on the mechanism of the antibacterial effect against $C$. perfringens.

\section{Conclusions}

In conclusion, the present work gives an example of isolation and structural identification of new biomolecules from a complex mixture of H. aspersa mucus using advanced, sophisticated instrumentation. As shown through different biotests, several of the mucus fractions have considerable antimicrobial activity, which could probably add to the arsenal of antibiotics as candidates with low resistance rates.

Supplementary Materials: The following are available online at http://www.mdpi.com/2227-9059/8/9/315/s1, SI 1. An alignment of amino acid sequences of some identified peptides from C. aspersum mucus with known antimicrobial peptides with data base AMPs by CAMPSing (http://www.campsign.bicnirrh.res.in/blast.php) and with proteins by BLAST (https://blast.ncbi.nlm.nih.gov). SI 2: Figure S1. Illustrations of sterile areas in investigation of antibacterial activity against model bacteria antibacterial effect of Sample 4 against Pseudomonas aureofaciens AP9; Figure S2. Illustrations of sterile areas in investigation of antibacterial activity against model bacteria antibacterial effect of Sample 4 against Brevibacillus laterosporus BT-271.

Author Contributions: Conceptualization, P.D. and Y.T.; investigations A.D., P.D., V.A., L.V., E.D., and N.Z.; methodology, A.D., P.D., L.V., Y.T., and P.D.; writing-original draft preparation, L.V., W.V., and P.D.; writing-review and editing, L.V., W.V., and P.D. All authors have read and agreed to the published version of the manuscript.

Funding: This research was carried out with the support of a project under contract No. DN 01/14 of 19.12.16, and National Scientific Program "Innovative Low-Toxic Biologically Active Means for Precision Medicine" (BioActiveMed), funded by the Scientific Research Fund of the Ministry of Education and Science in the Republic of Bulgaria and by Project VS.076.18N (FWO).

Conflicts of Interest: The authors declare no conflict of interest. The funders had no role in the design of the study; in the collection, analyses, or interpretation of data; in the writing of the manuscript, or in the decision to publish the results.

\section{References}

1. World Health Organization, 2015. Critically Important Antimicrobials for Human Medicine: Ranking of Antimicrobial Agents for Risk Management of Antimicrobial Resistance Due to Non-Human Use; 5th revision; World Health Organization: Geneva, Switzerland, 2017; Licence: CC BY-NC-SA 3.0 IGO. Available online: https://apps.who.int/iris/bitstream/handle/10665/255027/9789241512220-eng.pdf; jsessionid=DD014C6E76979E5E3ECE1BA519E14CA1? sequence=1 (accessed on 10 April 2017).

2. Totsika, M. Benefits and challenges of antivirulence antimicrobials at the dawn of the post-antibiotic era. Curr. Med. Chem. 2016, 6, 30-37. [CrossRef]

3. Giuliani, A.; Pirri, G.; Nicoletto, S.F. Antimicrobial peptides: An overview of a promising class of therapeutics. Cent. Eur. J. Biol. 2007, 2, 1-33. [CrossRef]

4. World Health Organization. Global Priority List of Antibiotic-Resistant Bacteria to Guide Research, Discovery, and Development of New Antibiotics. 2017. Available online: http://www.who.int/medicines/publications/ global-priority-list-antibiotic-resistant-bacteria (accessed on 17 April 2019).

5. Wiesner, J.; Vilcinskas, A. Antimicrobial peptides: The ancient arm of the human immune system. Virulence 2010, 1, 440-464. [CrossRef] [PubMed]

6. Zhang, L.; Gallo, R.L. Antimicrobial peptides. Curr. Biol. 2016, 26, R14-R19. [CrossRef] [PubMed] 
7. Guaní-Guerra, E.; Santos-Mendoza, T.; Lugo-Reyes, S.O.; Terán, L.M. Antimicrobial peptides: General overview and clinical implications in human health and disease. Clin. Immunol. 2010, 135, 1-11. [CrossRef]

8. Mahlapuu, M.; Hakansson, J.; Ringstad, L.; Björn, C. Antimicrobial Peptides: An Emerging Category of Therapeutic Agents. Front. Microbiol. 2016, 6, 194. [CrossRef]

9. Zharkova, M.; Orlov, D.S.; Golubeva, O.Y.; Chakchir, O.B.; Eliseev, I.E.; Grinchuk, T.M.; Shamova, O. Application of Antimicrobial Peptides of the Innate Immune System in Combination With Conventional Antibiotics-A Novel Way to Combat Antibiotic Resistance? Front. Microbiol. 2019, 9, 128. [CrossRef]

10. Brogden, K.A. Antimicrobial peptides: Pore formers or metabolic inhibitors in bacteria? Nat. Rev. Microbiol. 2005, 3, 238-250. [CrossRef]

11. Smith, V.J.; Desbois, A.P.; Dyrynda, E.A. Conventional and unconventional antimicrobials from fish, marine invertebrates and micro-algae. Mar. Drugs 2010, 8, 1213-1262. [CrossRef]

12. Jenssen, H.; Hamill, P.; Hancock, R.E. Peptide antimicrobial agents. Clin. Microbiol. Rev. 2006, 19, 491-511. [CrossRef] [PubMed]

13. Zhuang, J.; Coates, C.J.; Zhu, H.; Zhu, P.; Zujian, W.; Xie, L. Identification of candidate antimicrobial peptides derived from abalone hemocyanin. Dev. Comp. Immunol. 2015, 49, 96-102. [CrossRef] [PubMed]

14. Li, H.; Parisi, M.G.; Parrinello, N.; Cammarata, M.; Roch, P. Molluscan antimicrobial peptides, a review from activitybased evidences to computer-assisted sequences. Invertebr. Surviv. J. 2011, 8, 85-97.

15. Pitt, S.; Graham, M.A.; Dedi, C.G.; Taylor-Harris, P.M.; Gunn, A. Antimicrobial properties of mucus from the brown garden snail Helix aspersa. Br. J. Biomed. Sci. 2015, 72, 174-181. [CrossRef] [PubMed]

16. Dolashka, P.; Moshtanska, V.; Borisova, V.; Dolashki, A.; Stevanovic, S.; Dimanov, T.; Voelter, W. Antimicrobial proline-rich peptides from the hemolymph of marine snail Rapana venosa. Peptides 2011, 32, 1477-1483. [CrossRef]

17. Hubert, F.; Noël, T.; Roch, P. A Member of the Arthropod Defensin Family from Edible Mediterranean Mussels (Mytilus galloprovincialis). JBIC J. Boil. Inorg. Chem. 1996, 240, 302-306. [CrossRef]

18. Charlet, M.; Chernysh, S.; Philippe, H.; Hetru, C.; Hoffmann, J.A.; Bulet, P. Innate Immunity. J. Biol. Chem. 1996, 271, 21808-21813. [CrossRef]

19. Leoni, G.; De Poli, A.; Mardirossian, M.; Gambato, S.; Florian, F.; Venier, P.; Wilson, D.N.; Tossi, A.; Pallavicini, A.; Gerdol, M. Myticalins: A Novel Multigenic Family of Linear, Cationic Antimicrobial Peptides from Marine Mussels (Mytilus spp.). Mar. Drugs 2017, 15, 261. [CrossRef]

20. Dolashka, P.; Dolashki, A.; Wolfgang, V.; Jozef, V.B.; Stevanovic, S. Antimicrobial activity of peptides from the hemolymph of Helix lucorum snails. Int. J. Curr. Microbiol. App. Sci. 2015, 4, 1061-1071.

21. Dolashka, P.; Dolashki, A.; Velkova, L.; Stevanovic, S.; Molin, L.; Traldi, P.; Velikova, R.; Voelter, W. Bioactive compounds isolated from garden Snails. J. BioSci. Biotechnol. 2015, 147-155.

22. Pitt, S.; Hawthorne, J.A.; Garcia-Maya, M.; Alexandrovich, A.; Symonds, R.C.; Gunn, A. Identification and characterisation of anti-Pseudomonas aeruginosa proteins in mucus of the brown garden snail, Cornu aspersum. Br. J. Biomed. Sci. 2019, 76, 129-136. [CrossRef]

23. Zhong, J.; Wang, W.; Yang, X.; Yan, X.; Liu, R. A novel cysteine-rich antimicrobial peptide from the mucus of the snail of Achatina fulica. Peptides 2013, 39, 1-5. [CrossRef] [PubMed]

24. Velkova, L.; Nissimova, A.; Dolashki, A.; Daskalova, E.; Dolashka, P.; Topalova, Y. Glycine-rich peptides from Cornu aspersum snail with antibacterial activity. Bul Chem. Com. 2018, 50C, 169-175.

25. Dolashki, A.; Nissimova, A.; Daskalova, E.; Velkova, L.; Topalova, Y.; Hristova, P.; Traldi, P.; Voelter, W.; Dolashka, P. Structure and antibacterial activity of isolated peptides from the mucus of garden snail. Cornu aspersum. Bul. Chem. Com. 2018, 50C, 195-200.

26. Kostadinova, N.; Voynikov, Y.; Dolashki, A.; Krumova, E.; Abrashev, R.; Kowalewski, D.; Stevanovic, S.; Velkova, L.; Velikova, R.; Dolashka, P. Antioxidative screening of fractions from the mucus of garden snail Cornu aspersum. Bul. Chem. Com. 2018, 50C, 176-183.

27. Bradford, M.M. A rapid and sensitive method for the quantitation of microgram quantities of protein utilizing the principle of protein-dye binding. Anal. Biochem. 1976, 72, 248-254. [CrossRef]

28. Todorova, Y.; Yotinov, I.; Topalova, Y.; Marinova, P.; Benova, E.; Atanasova, M.; Bogdanov, T. Innovative sterilization technology—bacterial inactivation by cold argon plasma. BioDiscovery 2017, 20. [CrossRef]

29. Hauduroy, P.; Ehringer, G.; Urbain, A.; Guillot, G.; Magrou, J. Dictionnaire des Bactéries Pathogènes; Masson et Cie: Paris, France, 1937; pp. 1-597.

30. Heatley, N.G. A method for the assay of penicillin. Biochem. J. 1944, 38, 61-65. [CrossRef] 
31. Jones, R. NCCLS guidelines: Revised performance standards for antimicrobial disk susceptibility tests. Antimicrob. Newsl. 1984, 1, 64-65. [CrossRef]

32. CLSI. Method for Antifungal Disk Diffusion Susceptibility Testing of Yeasts, Approved Guideline; CLSI Document M44-A2; CLSI: Wayne, PA, USA, 2004.

33. Balouiri, M.; Sadiki, M.; Ibnsouda, S.K. Methods for in vitro evaluating antimicrobial activity: A review. J. Pharm. Anal. 2016, 6, 71-79. [CrossRef]

34. Tang, Y.-W.; Stratton, C.W. Advanced Techniques in Diagnostic Microbiology; Springer Science and Business Media LLC.: Berlin, Germany, 2006; pp. 711-740. Available online: https://link.springer.com/book/10.1007\% 2F978-3-319-95111-9 (accessed on 6 May 2010).

35. Bianchi-Bosisio, A. Proteins | Physiological Samples. In Encyclopedia of Analytical Science, 2nd ed.; Unita Socio Sanitaria: Milan, Italy, 2005; accepted 28 May 2005. [CrossRef]

36. Opdenakker, G.; Rudd, P.M.; Wormald, M.R.; Dwek, R.A.; Van Damme, J. Cells regulate the activities of cytokines by glycosylation. FASEB J. 1995, 9, 453-457. [CrossRef]

37. Moradi, S.V.; Hussein, W.M.; Varamini, P.; Simerska, P.; Toth, I. Glycosylation, an effective synthetic strategy to improve the bioavailability of therapeutic peptides. Chem. Sci. 2016, 7, 2492-2500. [CrossRef] [PubMed]

38. Bednarska, N.G.; Wren, B.W.; Willcocks, S.J. The importance of the glycosylation of antimicrobial peptides: Natural and synthetic approaches. Drug Discov. Today 2017, 22, 919-926. [CrossRef] [PubMed]

39. Lele, D.S.; Talat, S.; Kumari, S.; Srivastava, N.; Kaur, K.J. Understanding the importance of glycosylated threonine and stereospecific action of Drosocin, a Proline rich antimicrobial peptide. Eur. J. Med. Chem. 2015, 92, 637-647. [CrossRef] [PubMed]

40. Talat, S.; Thiruvikraman, M.; Kumari, S.; Kaur, K.J. Glycosylated analogs of formaecin I and drosocin exhibit differential pattern of antibacterial activity. Glycoconj. J. 2011, 28, 537-555. [CrossRef]

41. Huang, C.Y.; Hsu, J.-T.; Chung, P.-H.; Cheng, W.; Jiang, Y.-N.; Ju, Y.-T. Site-specific N-glycosylation of caprine lysostaphin restricts its bacteriolytic activity toward Staphylococcus aureus. Anim. Biotechnol. 2013, 24, 129-147. [CrossRef]

42. Harrison, R.L.; Jarvis, D.L. Protein N-glycosylation in the baculovirus-insect cell expression system and engineering of insect cells to produce 'mammalianized' recombinant glycoproteins. Insect Viruses Biotechnol. Appl. 2006, 68, 159-191.

43. Saikia, K.; Sravani, Y.D.; Ramakrishnan, V.; Chaudhary, N. Highly potent antimicrobial peptides from N-terminal membrane-binding region of E. coli. MreB. Sci. Rep. 2017, 7, 42994. [CrossRef]

44. Zasloff, M. Antimicrobial peptides of multicellular organisms. Nature 2002, 415, 389-395. [CrossRef]

45. Brown, K.L.; Hancock, R.E. Cationic host defense (antimicrobial) peptides. Curr. Opin. Immunol. 2006, 18, 24-30. [CrossRef]

46. Hancock, R.E.W.; Lehrer, R. Cationic peptides: A new source of antibiotics. Trends Biotechnol. 1998, 16, 82-88. [CrossRef]

47. Lei, J.; Sun, L.; Huang, S.; Zhu, C.; Li, P.; He, J.; Mackey, V.; Coy, D.H.; He, Q. The antimicrobial peptides and their potential clinical applications. Am. J. Transl. Res. 2019, 11, 3919-3931. [PubMed]

48. Raheem, N.; Straus, S.K. Mechanisms of Action for Antimicrobial Peptides with Antibacterial and Antibiofilm Functions. Front. Microbiol. 2019, 10, 2866. [CrossRef] [PubMed]

49. Chen, Y.; Guarnieri, M.T.; Vasil, A.I.; Vasil, M.L.; Mant, C.T.; Hodges, R.S. Role of peptide hydrophobicity in the mechanism of action of alpha-helical antimicrobial peptides. Antimicrob. Agents Chemother. 2007, 51, 1398-1406. [CrossRef] [PubMed]

50. Graf, M.; Mardirossian, M.; Nguyen, F.; Seefeldt, A.C.; Guichard, G.; Scocchi, M.; Innis, C.A.; Wilson, D.N. Proline-rich antimicrobial peptides targeting protein synthesis. Nat. Prod. Rep. 2017, 34, 702-711. [CrossRef] [PubMed]

51. Aisenbrey, C.; Marquette, A.; Bechinger, B. The Mechanisms of Action of Cationic Antimicrobial Peptides Refined by Novel Concepts from Biophysical Investigations. Adv. Exp. Med. Biol. 2019, 1117, 33-64.

52. Krizsan, A.; Volke, D.; Weinert, S.; Sträter, N.; Knappe, D.; Hoffmann, R. Insect-derived proline-rich antimicrobial peptides kill bacteria by inhibiting bacterial protein translation at the 70 S ribosome. Angew. Chem. Int. Ed. Engl. 2014, 53, 12236-12239. [CrossRef]

53. Gagnon, M.G.; Roy, R.N.; Lomakin, I.B.; Florin, T.; Mankin, A.S.; Steitz, T.A. Structures of proline-rich peptides bound to the ribosome reveal a common mechanism of protein synthesis inhibition. Nucleic Acids Res. 2016, 44, 2439-2450. [CrossRef] 
54. Baumann, T.; Kämpfer, U.; Schürch, S.; Schaller, J.; Largiadèr, C.R.; Nentwig, W.; Kuhn-Nentwig, L. Ctenidins: Antimicrobial glycine-rich peptides from the hemocytes of the spider Cupiennius salei. Cell. Mol. Life Sci. 2010, 67, 2787-2798. [CrossRef]

55. Lorenzini, D.M.; Junior, P.I.D.S.; Fogaça, A.C.; Bulet, P.; Daffre, S. Acanthoscurrin: A novel glycine-rich antimicrobial peptide constitutively expressed in the hemocytes of the spider Acanthoscurria gomesiana. Dev. Comp. Immunol. 2003, 27, 781-791. [CrossRef]

56. Waghu, F.H.; Barai, R.S.; Gurung, P.; Idicula-Thomas, S. CAMPR3: A database on sequences, structures and signatures of antimicrobial peptides: Table 1. Nucleic Acids Res. 2015, 44, D1094-D1097. [CrossRef]

57. Matsuzaki, K. Control of cell selectivity of antimicrobial peptides. Biochim. Biophys. Acta (BBA) Biomembr. 2009, 1788, 1687-1692. [CrossRef] [PubMed]

58. Harris, F.; Dennison, S.R.; Phoenix, D. Anionic Antimicrobial Peptides from Eukaryotic Organisms. Curr. Protein Pept. Sci. 2009, 10, 585-606. [CrossRef] [PubMed]

59. Dennison, S.R.; Harris, F.; Mura, M.; Phoenix, D.A. An Atlas of Anionic Antimicrobial Peptides from Amphibians. Curr. Protein Pept. Sci. 2018, 19, 823-838. [CrossRef] [PubMed]

60. Brogden, K.A.; Ackermann, M.; Huttner, K.M. Small, anionic, and charge-neutralizing propeptide fragments of zymogens are antimicrobial. Antimicrob. Agents Chemother. 1997, 41, 1615-1617. [CrossRef]

61. Malmsten, M.; Davoudi, M.; Walse, B.; Rydengard, V.; Pasupuleti, M.; Morgelin, M.; Schmidtchen, A. Antimicrobial peptides derived from growth factors. Growth Factors 2007, 25, 60-70. [CrossRef]

62. Mak, P. Hemocidins in a functional and structural context of human antimicrobial peptides. Front. Biosci. 2008, 13, 6859-6871. [CrossRef]

63. Dennison, S.R.; Whittaker, M.; Harris, F.; Phoenix, D.A. Anticancer alpha-helical peptides and structure/function relationships underpinning their interactions with tumour cell membranes. Curr. Protein Pept. Sci. 2006, 7, 487-499. [CrossRef]

64. Pelegrini, P.B.; Quirino, B.F.; Franco, O.L. Plant cyclotides: An unusual class of defense compounds. Peptides 2007, 28, 1475-1481. [CrossRef]

65. Gruber, C.W.; Cemazar, M.; Anderson, M.A.; Craik, D.J. Insecticidal plant cyclotides and related cystine knot toxins. Toxicon 2007, 49, 561-575. [CrossRef]

66. Sousa, J.C.; Berto, R.F.; Gois, E.A.; Fontenele-Cardi, N.C.; Honório-Júnior, J.E.; Konno, K.; Richardson, M.; Rocha, M.F.; Camargo, A.A.; Pimenta, D.C.; et al. Leptoglycin: A new Glycine/Leucine-rich antimicrobial peptide isolated from the skin secretion of the South American frog Leptodactylus pentadactylus (Leptodactylidae). Toxicon 2009, 54, 23-32. [CrossRef]

67. Markossian, K.A.; Zamyatnin, A.A.; Kurganov, B.I. Antibacterial proline-rich oligopeptides and their target proteins. Biochemistry (Mosc.) 2004, 69, 1082-1091. [CrossRef]

68. Haney, E.F.; Straus, S.K.; Hancock, R.E.W. Reassessing the Host Defense Peptide Landscape. Front. Chem. 2019, 7, 43. [CrossRef]

69. Álvarez-Ordóñez, A.; Begley, M.; Clifford, T.; Deasy, T.; Considine, K.; Hill, C. Structure-Activity Relationship of Synthetic Variants of the Milk-Derived Antimicrobial Peptide $\alpha$ s2-Casein f(183-207). Appl. Environ. Microbiol. 2013, 79, 5179-5185. [CrossRef]

70. Wang, G.; Mishra, B.; Lau, K.; Lushnikova, T.; Golla, R.; Wang, X. Antimicrobial Peptides in 2014. Pharmaceuticals 2015, 8, 123-150. [CrossRef]

71. Zhang, L.; Benz, R.; Hancock, R.E.W. Influence of proline residues on the antibacterial and synergistic activities of alpha-helical peptides. Biochemistry 1999, 38, 8102-8111. [CrossRef] [PubMed]

72. Suh, J.Y.; Lee, Y.T.; Park, C.B.; Lee, K.H.; Kim, S.C.; Choi, B.S. Structural and functional implications of a proline residue in the antimicrobial peptide gaegurin. Eur. J. Biochem. 1999, 266, 665-674. [CrossRef] [PubMed]

73. Park, C.B.; Kim, M.S.; Kim, S.C. A novel antimicrobial peptide from Bufo bufo gargarizans. Biochem. Biophys. Res. Commun. 1996, 218, 408-413. [CrossRef] [PubMed]

74. Morikawa, N.; Hagiwara, K.; Nakajima, T. Brevinin-1 and -2,unique antimicrobial peptides from the skin of the frog, Rana brevipoda porsa. Biochem. Biophys. Res. Commun. 1992, 189, 184-190. [CrossRef]

75. Lee, S.Y.; Söderhäll, K. Processing of an Antibacterial Peptide from Hemocyanin of the Freshwater Crayfish Pacifastacus leniusculus. J. Boil. Chem. 2002, 278, 7927-7933. [CrossRef] 
76. Ullal, A.J.; Litaker, R.W.; Noga, E.J. Antimicrobial peptides derived from hemoglobin are expressed in epithelium of channel catfish (Ictalurus punctatus, Rafinesque). Dev. Comp. Immunol. 2008, 32, 1301-1312. [CrossRef]

77. Herluinus, M.; Kriswandini, I.; Arijani, A.R. Antimicrobial proteins of snail mucus (Achatina fulica) against Streptococcus mutans and Aggregatibacter actinomycetemcomitans. Dent. J. 2014, 47, 31-36. 